\title{
Cólicas do lactente
}

\author{
Colic in infants
}

Jayme Murahovschi*

O tema os pediatras conhecem. Há mais de um século. Todo pediatra que acompanha crianças no ambulatório tem uma opinião sobre a causa e tem sua conduta, mas, no fundo, tem muitas dúvidas, que não foram elucidadas nesse tempo todo. Talvez porque o problema tenha sido subestimado, apesar de ser queixa extremamente freqüente ${ }^{1}$ e de causar grande ansiedade aos pais, familiares e ao próprio pediatra. Este não tem como comprovar suas próprias suposições porque não existem estudos organizados. $\mathrm{O}$ que existe são pesquisas fracionadas, cujos resultados lembram a história dos cegos que foram apalpar o elefante cada um saiu com uma idéia parcial na certeza de ter conhecido o todo.

É por isso que o estudo de coorte de Saavedra e colaboradores ${ }^{2}$ é muito bemvindo. É criativo num tema que parece rotineiro, tem sólidas bases epidemioló-

gicas num assunto em que predomina a opinião pessoal e sobram os problemas metodológicos.

Consultamos três livros de texto, dois nacionais e um clássico americano traduzido.

No livro do Instituto da Criança SP, a experiente pediatra Hedda A.O. Penna ${ }^{3}$ admite que as cólicas sejam devidas à incoordenação do sistema nervoso autônomo ou constituição neuropática ou hipertônica, e que a origem mais freqüentemente é emocional do que primariamente gastrintestinal.

O livro editado pelo grupo da Escola Paulista de Medicina ${ }^{4}$ apresenta um enfoque psicanalítico, em que as cólicas são indicadoras do desajuste no relacionamento mãe-bebê, sendo o corpo utilizado como meio de expressão desse desconforto.

\footnotetext{
* Presidente do Departamento de Pediatria Ambulatorial da Sociedade Brasileira de Pediatria.
}

No tratado de Nelson", o autor se posiciona: "nenhum fator isolado explica sistematicamente a cólica" e "um médico solidário é importante para a resolução do problema".

São oportunas algumas considerações.

O termo cólica se refere a uma dor abdominal aguda, espasmódica.

A cólica do lactente se refere ao choro súbito, inexplicado e inconsolável (não responde às medidas habituais de conforto). A cólica típica se manifesta como um ataque paroxístico de choro forte, agudo, estridente, "em crescendo". O lactente se estica, fica vermelho, vira a cabeça para os lados, as mãos ficam crispadas, as coxas fletidas sobre o abdome; com frequiência ocorre a eliminação de gases, que parece trazer um alívio temporário. Com breves pausas, o choro pode se prolongar por horas; $\mathrm{o}$ choro é inconsolável, o que traz aos pais sentimentos de frustração e impotência.

$\mathrm{Na}$ prática, a cólica é freqüentemente caracterizada apenas pelo choro sem motivo aparente.

Acontece que o choro é uma ferramenta, normal e fisiológica, de comunicação, usada pelo lactente nos seus primeiros meses de vida. Achar que existe um limiar a partir do qual o choro normal se transforma em cólica é ignorar o verdadeiro continuum que caracteriza os fenômenos biológicos, sendo que, neste caso, a cólica seria o extremo do espectro normal da variação do choro ${ }^{6}$. A cólica é um diagnóstico clínico, freqüentemente de exclusão, que não se apóia em nenhum dado de exame físico nem laboratorial. Mas os critérios clínicos pouco avançaram nos últimos anos, a tal ponto que os mais utilizados (com pequenas variantes) são os critérios de Wessel, publicados há quase meio século e conhecidos como a "regra dos 3": duram pelo menos 3 horas, ocorrem pelo menos 3 dias por semana e 
pelo menos 3 semanas seguidas; desaparecem aos 3 meses de vida. Acresce o curioso fato do choro com "hora certa", isto é, as cólicas ocorrem num horário predeterminado, geralmente no fim da tarde, início da noite (19-23 horas).

Na realidade, os critérios de Wessel foram desenvolvidos primariamente para propósitos de pesquisa, já que, para procurar a causa de um processo e respectiva terapia, para maximizar a força estatística, convém que a amostra seja constituída por casos puros, de diagnóstico indiscutível. Por isso, os critérios de Wessel apresentam mais especificidade do que sensibilidade, de modo que acarreta uma taxa alta de falso-negativos (deixam de incluir crianças com cólicas verdadeiras). Na prática, a cólica é diagnosticada em lactentes saudáveis sem causa detectável, cuja irritabilidade traz problemas consideráveis para as famílias que necessitam de assistência; por outro lado, limita a aplicabilidade de possíveis achados de pesquisas sobre a cólica verdadeira ${ }^{6}$.

A etiologia da cólica do lactente, que já é conhecida pelos pediatras há mais de um século, continua a representar um enigma. Diferentes causas que podem ser aditivas, mas freqüentemente são contraditórias, têm sido aventadas, e estas podem ser divididas em gastrintestinais e não gastrintestinais. A cólica pode ser uma variante normal e estaria relacionada a uma imaturidade fisiológica. É curioso notar que os prematuros têm o mesmo padrão de choro e de cólicas, e que atingem o pico com 6 semanas de idade gestacional, isto é, a mesma dos lactentes a termo.

Temperamento da criança, ansiedade dos pais (que pode ser agravada por inexperiência e falta de apoio), depressão materna, personalidade da mãe, problemas na dinâmica familiar e a possibilidade de seqüelas emocionais são aspectos que já foram levantados e apaixonadamente debatidos.

$\mathrm{Na}$ esfera gastrintestinal foram levantadas algumas hipóteses cujas respectivas pesquisas não foram conclusivas $^{7}$ :

Motilidade intestinal alterada - hiperperistaltismo colônico e pressão retal aumentada. Fala a favor dessa hipótese, a ação efetiva de alguns antiespasmódicos cujos efeitos colaterais, às vezes graves, impedem seu uso terapêutico.

Hormônios intestinais - a motilina, que exagera a peristalse intestinal, parece estar aumentada nos lactentes que sofrem de cólicas.

Excesso de ar intragastrintestinal - a aerofagia poderia ser causa, mas também pode ser conseqüência do choro. $\mathrm{O}$ uso de antiflatulentos, como a simeticona (freqüentemente utilizada na prática), não se mostrou mais eficaz que o placebo, em estudo multicêntrico randomizado, o que fala contra essa hipótese.

O excesso de gases também foi atribuído a uma má absorção fisiológica e transitória da lactose, mas as primeiras pesquisas não foram confirmadas.
Tipo de aleitamento - não se verificou diferença significativa entre crianças em aleitamento materno e as que recebem mamadeira, embora um estudo tenha mostrado que o pico da freqüência de cólicas era mais precoce nas crianças em aleitamento artificial (duas semanas de vida) do que nas amamentadas (seis semanas de vida).

Na prática pediátrica, os critérios de Wessel podem ser muito úteis para determinar a conduta. Os casos que se enquadram nesses critérios devem receber do pediatra explicação, tranqüilização e apoio. Os casos que se afastam muito dos critérios devem ser investigados.

Choro contínuo nas duas primeiras semanas de vida levantam a suspeita de fome, inclusive por mamadas ineficientes (controlar o peso). Nos casos associados à regurgitação acentuada e a mamadas nervosas, interrompidas, considerar refluxo gastresofágico, e nas famílias atópicas, em que o lactente apresenta choro acentuado logo após as mamadas, e especialmente se a criança tem outras manifestações alérgicas, pesquisar alergia ao leite de vaca, inclusive nas crianças que mamam leite de peito.

Como toda boa pesquisa, a de Saavedra e cols. dá algumas respostas, como a influência do desmame precoce (embora a cólica vespertina também ocorra na criança amamentada), e levanta muitas dúvidas.

Seria interessante comparar os lactentes com cólicas diagnosticadas pelos critérios de Wessel e as crianças chorosas pela percepção da mãe.

Quem sabe os autores se animem e aprofundem seu estudo num modo prospectivo e seqüencial, fazendo uma pesquisa epidemiológica e etnográfica, com entrevistas em profundidade e observações participantes.

Nesse sentido, a recente e excelente revisão de Bricks ${ }^{8}$ pode ser um bom ponto de apoio.

\section{Referências bibliográficas}

1. Luz JH, Severini MM, Cardoso M. Cólicas do lactente: a visão do pediatra. J Pediatr (Rio J) 1991;67:393-9.

2. Saavedra MAL, Costa JSD, Garcias G, Horta BL, Tomasi E, Mendonça R. Incidência de cólica no lactente e fatores associados: um estudo de coorte. J Pediatr (Rio J) 2003;79:115-22.

3. Penna HAO. Choro. In: Marcondes E, Costa Vaz, FA, Araujo Ramos, JL, Okay Y, editores. Pediatria Básica. $9^{a}$ ed. São Paulo: Sarvier; 2002.p.189.

4. Silveira MLM, Souza Campos, MLFS. O bebê. In: Carvalho ES, Carvalho WB, editores. Terapêutica e prática pediátrica. $2^{\mathrm{a}}$ ed. São Paulo: Atheneu; 2000.p.55-7.

5. Curran JS, Barness L. Cólica. In: Behrman RE, Kliegman RM, Jenson HB, editores. Nelson Tratado de Pediatria, $16^{\mathrm{a}}$ ed. Rio de Janeiro: Guanabara Koogan; 2002.p.168.

6. Garrison MM, Christakis DM. Infant colic. Pediatric Case Reviews 2001;191:19-24.

7. Gupta SK. Is colic a gastrointestinal disorder? Curr Opin Pediatr 2002;14:588-92.

8. Bricks LF. Choro excessivo e cólica em lactentes. Pediatria (São Paulo) 2001;23(4):305-19. 